\title{
Analisa Sanctification of Parenting Orangtua terhadap Konsep Diri Remaja: Studi Kasus di Keluarga Dai
}

\author{
Azizah Fajar Islam ${ }^{1 *}$, Nurwahidin, Thobib Al-Asyhar \\ ${ }^{1}$ Kajian Timur Tengah dan Islam, Sekolah Kajian Strategik dan Global, Universitas Indonesia, \\ Jl. Margonda Raya, Pondok Cina, Beji, Kota Depok, Jawa Barat 16424, Indonesia \\ *Email Korespondensi: zhiza.fajar27@gmail.com
}

Kata kunci: sanctification of parenting, orangtua, konsep diri, remaja, keluarga dai

Keyword: sanctification of parenting, parents, self-concept, adolescents, dai's family

\section{A B S T R A K}

Dai dan keluarga dai juga menjadi teladan dan acuan umat muslim dalam membentuk keluarga islam yang ideal. Namun, usaha untuk membangun keluarga islam yang ideal tidak selalu berjalan lancar, beberapa remaja dari keluarga dai diketahui melakukan kenakalan remaja. Penelitian ini bertujuan untuk melihat gambaran pemaknaan yang sakral sebagai orangtua atau disebut sebagai sanctification of parenting orangtua dalam memaknai perannya dan gambaran konsep diri remaja di keluarga dai.Sanctification of parenting memiliki dua tipe, manifestation of God dan sacred quality. Penggalian sanctification of parenting dilakukan dengan menggali pemaknaan orang tua terhadap peran, hubungan dan objek serta upaya menghadirkan sanctification of parenting. Penelitian ini menggunakan penelitian kualitatif deskriptif untuk memberikan gambaran bagaimana sanctification of parenting orang tua dan konsep diri remaja dari keluarga dai. Subjek dalam penelitian ini terdiri tiga pasang orang tua dan remaja dari keluarga dai. Hasil dari penelitian ini memperlihatkan bahwa sanctification of parenting yang dimiliki orangtua menunjukkan bahwa orangtua menerapkan nilai-nilai dan ajaran islam dalam pengasuhannya dan keluarga dai lebih mudah memaknai sanctification of parenting dengan tipe manifestation of God dibandingkan dengan sacred quality. Konsep diri remaja menunjukkan remaja tidak merasa puas dengan dirinya karena belum dapat memenuhi harapan orang tua dan belum mengenali dirinya dengan baik.

\section{A B S TRACT}

Dai and the dai's family are also role models and references for Muslims in forming an ideal Islamic family. However, efforts to build an ideal Islamic family do not always go smoothly, some teenagers from the dai's family are known to do juvenile delinquency. This study aims to see a picture of the meaning of the sacred as a parent or referred to as a sanctification of parenting parents in interpreting their role and description of the self-concept of adolescents in the dai's family. Certification of parenting has two types, manifestation of God and sacred quality. Excavation of sanctification of parenting is done by exploring the meaning of parents on the roles, relationships and objects and efforts to present sanctification of parenting. This research uses descriptive qualitative research to give an idea of how the parental sanctification of parenting and adolescent selfconcept from the dai's family. The subjects in this study consisted of three pairs of parents and adolescents from the dai's family. The results of this study show that parentalsanctification of parenting shows that parents apply the values and teachings of Islam in their care and the family is easier to interpret sanctification of parenting with the type of manifestation of God compared to sacred quality. Self-concept of adolescents shows adolescents do not feel satisfied with themselves because they have not been able to meet the expectations of parents and have not recognized themselves well. 
Saat ini penelitian mengenai sanctification dalam pengasuhan belum banyak dilakukan, terutama kaitannya dengan konsep diri remaja. keberagamaan memiliki keterkaitan dalam melindungi sebuah keluarga (Utting, 2007), terutama pada keluarga dai yang menjadi teladan bagi umat muslim. Agama selain berkaitan dengan keluarga juga berkaitan dengan pengasuhan. Religiusitas orang tua diprediksi akan membentuk pola asuh otoritatif (Gunnoe, 1999) dan tujuan serta nilainilai yang sesuai dengan agamanya (Pargament dan Mahoney, 2001).

Dai sebagai penyeru dan
pengingat umat muslim secara
otomatis menjadi teladan bagi umat
muslim. Seorang dai memiliki
kewajiban moral yang menjadi
sebuah kode etik bagi seorang
pendakwah yaitu sebelum dai
menyampaikan dakwahnya kepada
masyarakat, dai harus melaksanakan
dakwah kepada keluarganya lebih dulu
(Akhirudin,2017). Sehingga jika dai
berdakwah kepada masyarakat, namun
membiarkan keluarganya tidak sesuai
dengan nilai-nilai islam akan dianggap
menyimpang.

Di sisi lain, remaja hari ini memiliki tugas perkembangan untuk membentuk identitas dirinya (Santrock, 2010). Identitas diri merupakan pondasi yang akan membangun konsep diri pada remaja (DeHart, Sroufe, \& Cooper,2004). Banyak faktor yang mempengaruhi perkembangan konsep diri, salah satunya adalah lingkungan sosial (middlebrook, 1980). Keluarga merupakan lingkungan sosial pertama bagi remaja dan orang tua menjadi significant other yang berpengaruh pada konsep diri remaja (Cooley, 1902).
Masa remaja merupakan masa yang kritis dan sulit (Hasan, 2006; Santrock, 2010). Tidak jarang remaja yang mengalami krisis dan melakukan berbagai kenakalan dan tindakan kriminal. Penelitian ini menjadi penting untuk dilakukan dan hasil penelitian ini dapat menjadi pertimbangan dalam menyelesaikan permasalahan yang terjadi pada remaja. penelitian ini dilakukan pada keluarga da'i yang secara personal memiliki keinginan untuk menjalankan nilai dan ajaran agama islam untuk dirinya dan keluarganya. Studi kasus pada keluarga da'i membantu peneliti menggali pemaknaan orangtua dari keluarga dai sebagai orang tua dalam penelitian ini.

Fokus dari makalah ini adalah untuk menyajikan temuan penelitian yang berkaitan dengan konsep diri remaja yang menerima pengasuhan dengan unsur keberagamaan dari orang tua yang memiliki aktifitas sebagai seorang Da'i. Pertanyaan yang muncul dalam penelitian ini adalah: bagaimana sanctification of parenting dai sebagai orang tua dan bagaimana konsep diri remaja yang terbentuk melalui pengasuhan yang dilakukan oleh orang tua? Pengetahuan mengenai hal ini akan memberikan kebermanfaatan pada lembaga pendidikan, secara praktis akan memberikan masukan kepada orang tua dan konsultan pendidikan dan keluarga, dan pada peneliti yang mengembangkan pengetahuan tentang keluarga dan remaja.

\section{Tinjauan Teoritis}

\section{Konsep Diri Remaja}

Konsep diri berkembang sejalan dengan pertumbuhan individu, karena konsep diri bukan sesuatu yang telah ada sejak lahir. Salah satu tugas perkembangan sosial remaja adalah pembentukan identitas (Santrock,2010). 
Dalam pembentukan identitas, tingkat identifikasi pada orangtua oleh remaja sejak kanak-kanak sampai masa remaja sangat berperan dalam memberikan arah pembentukan identitas diri remaja. Semua sikap orangtua menjadi sumber identifikasi bagi remaja dan menjadi bagian dalam pembentukan identitas (Marcia, 1993).

Perkembangan Konsep diri semakin stabil seiring dengan pertambahan usia (Marsh \& Craven, 1998). Perkembangan konsep diri akan membentuk konsep diri yang positif atau negative Calhoun (1990). Mack dan Ablon (dalam Henson \& Eller, 1999) membagi perkembangan konsep diri menjadi beberapa tahapan. Perkembangan konsep diri di masa remaja merupakan tahapan terakhir dalam perkembangan konsep diri remaja. Hal ini tidak membuat perkembangan konsep diri remaja terhenti pada tahap ini. Tahap remaja menjadi tahap akhir, karena pada tahap ini remaja mengalami perkembangan puncak kemampuan kognitif dan perubahan fisik. Remaja memiliki kemandirian yang lebih tinggi.

\section{Sanctification of Parenting}

sanctification merupakan sebuah konsep psikospiritual yang mengkolaborasikan sebuah pemahaman dan persepsi seseorang terhadap sesuatu yang dianggap sakral dan sudut pandang spiritual yang dimilikinya. Seseorang memiliki sebuah pamahaman yang substantif dan unik dengan menggunakan sudut pandang agama (Mahoney, 2005) dan kekuatan spiritual terhadap kehidupan dan hubungannya dengan orang lain. Sanctification merupakan persepsi seseorang pada objek, hubungan dan peran (Mahoney,dkk.2003).

$$
\text { Sanctification dalam }
$$

pengasuhan artinya adalah persepsi dimana orangtua memasukkan makna dan peran orangtua sebagai pengasuh dalam pemaknaan yang sakral dan memiliki keterkaitan dengan Tuhan. Selain pada peran, makna sakral tersebut juga didapat dari proses pengasuhan yang dilakukan oleh orangtua. Pemaknaan sanctification dalam pengasuhan lahir dalam bentuk praktik pengasuhan yang sesuai dengan perintah Tuhan (Volling, Mahoney, Rauer, 2009).

Mahoney (2005) juga menjelaskan mengenai cara yang dapat dilakukan untuk membentuk sanctification dalam diri seseorang. Mahoney membedakannya dalam dua cara, yaitu dengan manifestation of God dan sacred qualities. Manifestation of God terjadi dengan menyandarkan sebuah objek, hubungan dan peran dengan kekuatan yang sangat besar atau keagungan Tuhan. Persepsi orangtua yang terbangun dengan memeluk sebuah agama membentuk sebuah kepercayaan mengenai keagungan Tuhan dan mengaitkannya terhadap sebuah benda, hubungannya dengan makhluk lain dan perannya di lingkungan sebagai seseorang yang memiliki identitas agama, nilai serta ajaran agama yang dianutnya. Sacred quality dapat dimiliki oleh seseorang yang menganut agama tertentu dan yang tidak memiliki kepercayaan pada keberadaan kekuatan spiritual yang lebih tinggi. Tipe ini dapat terjadi saat orangtua melakukan penghayatan terhadap peran pengasuhan dan kegiatan sebagai sesuatu yang mulia, penuh keberkahan, atau dengan makna lainnya.

\section{Pengasuhan dan Konsep diri remaja}

Keluarga memegang peran penting bagi konsep diri individu melalui berbagai pengalaman awal yang diterima oleh individu (Combs \& Snygg dala Fitts, 1971). Keluarga 
menjadi salah satu bagian significant other individu unutk belajar dan membentuk persepsi mengenai dirinya sendiri (Fitts, 1971) Rekognisi dari orangtua dan guru akan pencapaian mereka inilah yang akan mengarahkan konsep diri remaja tersebut (Gage \& Berliner, 1992). Pengasuhan yang dilakukan oleh orangtua berpengaruh pada pembentukan identitas remaja (Romano,2004).

Konsep diri remaja dipengaruhi oleh pengalaman mereka dengan orangorang disekitarnya, baik itu pengalaman positif dan pengalaman negatif. berdasarkan penelitian yang telah dilakukan, diantara hanya gaya pengasuhan, hanya gaya pengasuhan otoritatif saja yang memiliki hubungan yang signifikan dengan perkembangan konsep diri remaja di Malaysia oleh Rahman dkk. (2017) dan Iran (Niaraku dan Rahimi,2012).

\section{METODE PENELITIAN}

Pendekatan penelitian kualitatif dengan pendekatan studi kasus merupakan pendekatan penelitian yang mengacu pada pemahaman yang utuh dan terintegrasi mengenai fakta dan dimensi dari kasus khusus (Poerwandari, 2013). Studi kasus dalam penelitian ini merupakan upaya untuk menggali lebih dalam berdasarkan kasus khusus. Dengan melihat kasus pemaknaan sanctification of parenting pada keluarga dai peneliti dapat lebih dekat memahami konsep diri remaja dan pengasuhan yang diberikan oleh orang tuanya sehingga

\begin{tabular}{|l|l|l|l|l|}
\hline & & \multicolumn{3}{|c|}{ S } \\
\cline { 3 - 5 } No. & D & Muthi & Farhan & Ahmad \\
\hline 1. & Usia & 17 tahun & 19 tahun & 18 \\
\hline 2. & Pendidik & SMA & Kuliah & Kuliah \\
\hline 3. & Urutan & Pertama & Anak Ke- & Anak \\
\hline 4. & Jumlah & 2 saudara & 4 Saudara & 4 \\
\hline
\end{tabular}

Tabel 2. Data Subjek Remaja memungkinkan untuk melihat gambaran sanctification of parenting orang tua dan konsep diri remaja.

\section{HASIL PENELITIAN}

Hasil penelitian ini didasarkan pada wawancara kualitatif kepada orang tua dan remaja yang berasal dari tiga keluarga, dimana orang tuanya beraktifitas sebagai seorang dai. Subjek penelitian dipilih melalui informasi dari masyarakat tentang keluarga da'i dan bertanya ketersediaan mereka untuk berpartisipasi dalam penelitian. Dalam wawancara ini, terdapat tiga orang ibu dan tiga orang remaja, 2 diantaranya adalah laki-laki dan seorang perempuan. Wawancara berlangsung selama satu sampai dua jam. Berdasarkan tiga kelompok variasi, paling sulit menemukan single mother sebagai da'i. Sebagian besar subjek kesulitan meluangkan waktu untuk wawancara. Tiga remaja yang diwawancara memiliki keadaan yang beragam, seperti usia, jenis kelamin dan urutan kelahiran didalam keluarga. Berdasarkan pengambilan data yang dilakukan melalui wawancara dan observasi, didapat data dari masingmasing subjek. Data subjek akan dijabarkan melalui table dibawah ini.

\begin{tabular}{|l|l|l|l|l|}
\hline \multirow{2}{*}{ No. } & \multirow{2}{*}{ D } & \multicolumn{2}{|c|}{ S } \\
\cline { 3 - 5 } & Ani & Sani & Ningsih \\
\hline 1. & Usia & 44 tahun & 49 tahun & 54 tahun \\
\hline 2. & Suku & Jawa & Aceh & Betawi \\
\hline 3. & Pendidika & SMA & S1 & SMA \\
\hline 4. & Pekerjaan & Guru Ngaji & Dosen & Pendakwah \\
\hline
\end{tabular}

Tabel 1. Data Subjek Orangtua

Wawancara yang dilakukan kepada orang tua memiliki tujuan untuk mengetahui sanctification of parenting orang tua. Wawancara yang dilakukan kepada remaja memiliki dua tujuan. Tujuan yang pertama, melakukan validasi informasi tentang sanctification of parenting orang tua dan menyelidiki konsep diri internal 
dan eksternal remaja. Wawancara dengan orang tua dan remaja dilakukan secara terpisah dan tidak bersama-sama.

Jumlah wawancara yang dilakukan sebanyak 6 yang berasal dari 3 keluarga. Jumlah ini memenuhi jumlah subjek dalam penelitian kualitatif. Wawancara kepada subjek dilakukan sebanyak dua kali dengan bertemu langsung dan tatap muka, sehingga peneliti dapat melihat langsung cara subjek menyampaikan dan bahasa tubuh yang muncul. Wawancara direkam dengan perekam suara dan informasi dalam penelitian ini terjamin kerahasiaannya. Peneliti melakukan wawancara di rumah subjek dengan orang tua dan di tempat remaja berkumpul dengan subjek remaja. Dalam penelitian ini terdapat resiko orang tua hanya akan menyampaikan pengasuhan yang baik dan tidak menyampaikan kesulitan dan kendala, namun resiko tersebut dapat teratasi. Peneliti mengkonfirmasi informasi yang disampaikan kepada orang tua kepada remaja.

Subjek wawancara orang tua semuanya adalah ibu. Usia subjek dalam rentang usia 45 tahun sampai 60 tahun. Dua diantaranya seorang Da'i. Diawal wawancara peneliti menggali lebih dalam mengenai aktifitas orang tua seperti jadwal kegiatan dan Ketiga narasumber dalam menghadirkan sanctification of parenting menggunakan ketiga cara tersebut. Baik Ani, Sani, dan Ningsih. Hal tersebut terlihat saat ketiganya mengucapkan kata-kata zikir seperti Alhmadulillah, Subhanallah, Masya Allah, dan kata-kata lainnya. Ketiga narasumber juga dalam melaksanakan ibadah dan menekankan melaksanakan ibadah wajib kepada anak-anaknya. Pada cara terakhir, semua narasumber juga menceritakan kisah dan pengalamannya tentang rosul dan kekuasaan Allah. Bukan hanya itu, kesibukan orang tua dan permasalahan yang dihadapi orang tua dalam menghadapi remaja remaja.

\section{PEMBAHASAN}

\section{Sanctification of parenting}

Untuk menghadirkan sanctification of parenting seseorang dapat melakukan beberapa hal, seperti menggunakan ungkapan pujian atau istilah khusus dalam agama, dalam agama Islam bisa di sebuh sebagai zikir, upaya yang kedua adalah dengan melakukan ritual ibadah, dan yang terakhir melalui kisah dan pengalaman yang berkaitan dengan tema spiritual (Butler dan Harper,

1984). Berikut adalah tabel upaya menghadirkan sanctification of parenting pada orangtua penerapannya dan dalam pengasuhan anak.

\begin{tabular}{|l|l|l|l|}
\hline Aspek & Ani & Sani & Ningsih \\
\hline Istilah agama & - Ya & - Ya & - Ya \\
\hline Ritual ibadah & - Ya & - Ya & - Ya \\
\hline $\begin{array}{l}\text { Kisah dan } \\
\text { Pengalaman } \\
\text { Spiritual }\end{array}$ & - Ya & - Ya & - Ya \\
\hline
\end{tabular}

Tabel 3 Pengupayaan sanctification of parenting antar subjek

ketiganya juga berusaha menghadirkan Allah dalam setiap peristiwa dan keadaan.

\section{Manifestation of God}

Manifestation of god merupakan sebuah cara untuk memiliki sanctification of parenting yang dilakukan oleh orangtua yang memeluk agama tertentu (Mahoney, 2005). Orangtua memaknai sanctification of parenting dengan menyandarkan segalanya kepada Allah. Terlihat dari bagaimana ketiga narasumber mengaitkan 
perannya sebagai orang tua, hubungan ketiganya dengan anakanak mereka, dan keberadaan anak. Pemaknaan Manifestation of god terbentuk melalui pemahaman narasumber terhadap pandangan agama tentang orang tua dan anak (Ulwan,2016). Termasuk keadalamnya bagaimana keutamaan, hak dan kewajiban. Berikut adalah tabel pemaknaan pengasuhan dengan Manifestation of god antar subjek.

\begin{tabular}{|c|c|c|c|}
\hline Aspek & Ani & Sani & Ningsih \\
\hline \multicolumn{4}{|c|}{ Peran sebagai orangtua } \\
\hline $\begin{array}{l}\text { Peran } \\
\text { sebagai } \\
\text { orangtua }\end{array}$ & $\begin{array}{l}\text {-Mendidik } \\
\text { dan } \\
\text { membentuk } \\
\text { Perilaku }\end{array}$ & $\begin{array}{l}\text { - Berperan } \\
\text { sebagai } \\
\text { orangtua dan } \\
\text { teman }\end{array}$ & \begin{tabular}{|l} 
Berperan \\
dalam \\
mendidik \\
anak
\end{tabular} \\
\hline \multicolumn{4}{|c|}{ Hubungan orangtua dan anak } \\
\hline $\begin{array}{l}\text { Hubungan } \\
\text { orangtua }\end{array}$ & $\begin{array}{l}- \\
\text { Hubungan } \\
\text { dengan } \\
\text { orangtua } \\
\text { dan anak } \\
\text { sebagai } \\
\text { sesuatu } \\
\text { yang } \\
\text { berharga }\end{array}$ & $\begin{array}{l}\text { - Hubungan } \\
\text { dengan } \\
\text { orangtua dan } \\
\text { anak sebagai } \\
\text { sesuatu } \\
\text { amanah }\end{array}$ & $\begin{array}{l}\text {-Meyakini } \\
\text { bahwa } \\
\text { Allah } \\
\text { menjaga } \\
\text { anak dan } \\
\text { berserah } \\
\text { diri } \\
\text { kepada } \\
\text { Allah }\end{array}$ \\
\hline
\end{tabular}

memiliki peran sebagai pendidik. Begitu pula yang dijelaskan oleh Ulwan (2016) dan Suwaid (2010). Bahwa orangtua memiliki kewajiban dalam memberikan pendidikan kepada anak- anaknya dengan berbagai bentuk pendidikan. Pada Sani, Ia memaknai perannya sebagai orangtua dengan memandang peran yang dapat dilakukan oleh orangtua.

Pemaknaan hubungan orangtua dan anak dimaknai sebagai kualitas hubungan oleh Ani dan Ningsih. Ani menilai bahwa hubungannya dengan anaknya adalah sesuatu yang sangat berharga. Keadaan anak dan kualitas

\begin{tabular}{|c|c|c|c|}
\hline \begin{tabular}{|l|} 
Nilai yang \\
hubungan \\
dan anak
\end{tabular} & $\begin{array}{l}- \\
\text { Menanam } \\
\text { kan nilai } \\
\text { tentang }\end{array}$ & $\begin{array}{l}\text { - Menanamkan } \\
\text { nilaiAkhlaq } \\
\text { baik dan } \\
\text { keteladanan }\end{array}$ & $\begin{array}{l}\text { Meng } \\
\text { ajak } \\
\text { anak } \\
\text { untuk }\end{array}$ \\
\hline \multicolumn{4}{|c|}{ Keberadaan anak } \\
\hline $\begin{array}{l}\text { Keberadaa } \\
\mathrm{n} \text { anak }\end{array}$ & $\begin{array}{l}\text { - Anak } \\
\text { adalah } \\
\text { objek } \\
\text { dakwah }\end{array}$ & $\begin{array}{l}\text { - Anak adalah } \\
\text { Amanah } \\
\text { dari Allah }\end{array}$ & $\begin{array}{l}\text { Anak } \\
\text { adalah } \\
\text { nikmat } \\
\text { dari } \\
\text { Allah }\end{array}$ \\
\hline \begin{tabular}{|l|} 
Peran \\
keberadaa \\
$\mathrm{n}$ anak
\end{tabular} & $\begin{array}{l}\text { - Allah } \\
\text { berperan } \\
\text { dalam } \\
\text { mencipt } \\
\text { akan } \\
\text { dan } \\
\text { mentakd } \\
\text { irkan }\end{array}$ & \begin{tabular}{|l} 
- Allah \\
menciptakan \\
dan \\
mengizinkan, \\
sehingga anak \\
h harus dekat \\
dengan Allah
\end{tabular} & $\begin{array}{l}\text { - Allah } \\
\text { meridhoi } \\
\text { anak- } \\
\text { anak dan } \\
\text { memberi } \\
\text { kan } \\
\text { penjagaa } \\
\text { n dan } \\
\text { keselam } \\
\text { atan }\end{array}$ \\
\hline
\end{tabular}

Tabel 4 Pemaknaan manifestation of god antar subjek

Peran sebagai orangtua tidak lepas dari tugas orangtua. Demikian Ani, dan Ningsih memaknai perannya. Ani dan Ningsih dalam memandang bahwa sebagai orangtua mereka

hubungan antara orangtua dan anak tidak sama pada setiap orang, ada yang keadaan anaknya tidak baik, ada pula yang memiliki hubungan yang tidak baik. Berbeda dengan pemaknaan Sari mengenai hubungannya dengan anak. Sani melihat hubungan seorang orangtua dan anak sebagai sebuah amanah.

Ketiganyanya memiliki cara yang beragam untuk menjaga hubungan mereka dengan anak-anak. Ani menjaga hubungannya dengan anak dengan mencoba memposisikan dirinya dalam keadaan anak-anaknya. Sedangkan Sani menjada hubungan dengan cara membangun 
komunikasi yang efekstif dengan anak. Sani mencoba membuka dialog dengan anak. Pada Ningsih, Ningsih mencoba menjaga hubungan dengan anak-anaknya dengan mendoakan mereka memenuhi kebutuhan mereka.

Kehadiran anak memberikan makna tersendiri bagi masing-masing orang orangtua. Ketiga narasumber memaknai peran Allah dalam keberadaan seorang anak sama. Allah berperan dalam penciptaan seorang anak, hal ini serupa yang dipaparkan Hasan (2010) dalam proses perkembangan manusia. Baik Ani, Sani maupun Ningsih memiliki pemaknaan yang berbeda dalam memaknai anak. Ani memandang anak adalah sebagai objek dakwah yang perlu dididik dan diberikan pengajaran. Ani memaknai peran Allah pada anak dan keberadaan anak dengan meyakini bahwa Allah dengan menghadirkan anak dan menjadikannya sebagai orangtua. Kehadiran anak adalah hal yang tidak semua orang dapat merasakannya. Sehingga sebagai orangtua Ani merasa bersyukur kepada Allah dalam kehadiran anak-anak. Sani memandang anak adalah sebuah amanah yang dititipkan kepadanya dan suaminya. Sehingga menjadi tugas

Tabel 5 Pemaknaan Sacred Quality antar subjek

\section{Konsep Diri Remaja}

\section{Dimensi Internal}

Dimensi internal merupakan penghayatan pada identitas diri, tingkahlaku dan penilaian atas dirinya. Dimensi ini terdiri dari tiga aspek, yaitu diri identitas (the identity self), diri perilaku (the behavioral self) dan diri penilai (the judging self). Berikut adalah tabel dimensi internal antar subjek.

\begin{tabular}{|l|l|l|l|}
\hline Aspek & Muthi & Ahmad & Farhan \\
\hline Self Identity \\
\hline
\end{tabular}

Sani dan suaminya untuk menjaga anak-anaknya sehingga tidak menyalahi fitrah anak.

\section{Sacred Quality}

Sacred quality merupakan persepsi seseorang dalam memaknai objek, hubungan atau peran sebagai sesuatu yang memiliki karakter spiritual (Mahoney,dkk. 2003). Sacred quality yang dimiliki oleh para narasumber terbentuk dengan berbagai cara. Ada yang terbentuk melalui pengalamannya pribadi, kisah dan pengalaman orang lain seperti teman atau ibu kandung, dan keyakinan pada ajaran agama. Berikut ini adalah tabel yang berisi tentang karakter spiritual yang muncul pada diri semua subjek.

\begin{tabular}{|c|c|c|c|}
\hline Aspek & Ani & Sani & Ningsih \\
\hline \multirow{4}{*}{$\begin{array}{l}\text { Peran } \\
\text { sebagai } \\
\text { orangtua }\end{array}$} & \multirow{4}{*}{\begin{tabular}{|l|} 
- Kemualiaan \\
- Keajaiban \\
- Menginspirasi \\
- Kenikmatan \\
- Bersyukur
\end{tabular}} & \multirow{4}{*}{$\begin{array}{l}\text { - Kemuliaan } \\
\text { - Keajaiban } \\
\text { - Kenikmatan }\end{array}$} & - Kemuliaan \\
\hline & & & - \\
\hline & & & - Kenikmatan \\
\hline & & & \\
\hline $\begin{array}{l}\text { Hubungan } \\
\text { dan anak }\end{array}$ & $\begin{array}{l}\text { Kemuliaan } \\
\text { Kesucian } \\
\text { Menginspirasi }\end{array}$ & $\begin{array}{l}\text { - Kemuliaan } \\
\text { - Kesucian }\end{array}$ & $\begin{array}{l}\text { - Kemuliaan } \\
- \\
\therefore\end{array}$ \\
\hline $\begin{array}{l}\text { Keberadaan } \\
\text { anak }\end{array}$ & $\begin{array}{l}\text { - Keberkahan } \\
\text { - Keajaiban } \\
- \\
\text { Menginspirasi }\end{array}$ & $\begin{array}{l}\text { - Keberkahan } \\
\text { - Keajaiban }\end{array}$ & - Keberkahan \\
\hline
\end{tabular}

\begin{tabular}{|c|c|c|c|c|}
\hline $\begin{array}{l}\text { Gambaran } \\
\text { diri sebagai } \\
\text { keluarga } \\
\text { da'i }\end{array}$ & $\begin{array}{l}\text { Berbeda, } \\
\text { namun tidak } \\
\text { ingin } \\
\text { terlihat } \\
\text { berbeda } \\
\text { dengan } \\
\text { teman- }\end{array}$ & $\begin{array}{l}\text { Tidak } \\
\text { mau } \\
\text { dikaitka } \\
\mathrm{n} \\
\text { den } \\
\text { gan } \\
\text { ora }\end{array}$ & \multicolumn{2}{|c|}{$\begin{array}{l}\text { Tidak pantas } \\
\text { untuk } \\
\text { menjadi } \\
\text { penerus } \\
\text { orangtua }\end{array}$} \\
\hline \multicolumn{5}{|c|}{ Self behavior } \\
\hline $\begin{array}{l}\text { pengaruh } \\
\text { status } \\
\text { keluarga } \\
\text { pada } \\
\text { perilaku }\end{array}$ & $\begin{array}{l}\text { Tidak } \\
\text { konsisten } \\
\text { antara } \\
\text { norma dan } \\
\text { perilaku }\end{array}$ & \multicolumn{2}{|c|}{$\begin{array}{l}\text { Mencari tahu } \\
\text { perilaku } \\
\text { yang tepat dan } \\
\text { sesuai }\end{array}$} & $\begin{array}{l}\text { Tidak } \\
\text { berpe } \\
\text { ngaru } \\
\mathrm{h}\end{array}$ \\
\hline \multicolumn{5}{|l|}{ Self Judging } \\
\hline penilaian & Belum baik & Belum & \multicolumn{2}{|c|}{ Tidak baik } \\
\hline
\end{tabular}

Secara umum, Muthi, Ahmad dan Farhan cenderung menggambarkan diri 
mereka dengan penilaian-penilaian yang negatif. Berdasarkan pengakuan ketiga narasumber. Mereka merasa memiliki pribadi yang tidak baik karena belum dapat memenuhi harapan keduaorangtua. Ketiganya masih melakukan hal-hal yang tidak diperbolehkan dalam Islam atau yang tidak dianggap baik dalam Islam, seperti menunda sholat, tidur setelah subuh.

Mereka juga merasa sebagai anak dari seorang da'i memiliki perbedaan dengan remaja yang berasal dari keluarga bukan da'i. Kesadaran ini terbangun karena tanggapan dan respon orang lain. Seperti yang dijelaskan Rosenberg (1989) yang menjelaskan mengenai social comparison. Rosenbeg mengungkapkan bahwa lingkungan memiliki peran dalam membentuk konsep diri. Baik Muthi, Ahmad dan Farhan ketiganya menganggap diri mereka berbeda karena orang-orang yang mengenali mereka sebagai anak dari keluarga da'i menekankan harapan

Dimensi eksternal merupakan hasil dari penghayatan dan penilaian seseorang dalam hubungannya dengan dunia disekitarnya, khususnya interaksi sosial yang berkaitan dengan peranperan individu di lingkungan sosialnya. Dimensi eksternal terdiri dari lima aspek, yaitu diri fisik ( physical self), diri etik moral (moral ethical self), diri personal (personal self), diri keluarga (family self), dan diri sosial (social self). Berikut ini adalah tabel dimensi eksternal antar subjek.

\begin{tabular}{|c|c|c|c|}
\hline Aspek & Muthi & Ahmad & Farhan \\
\hline \multicolumn{4}{|c|}{ Self Physic } \\
\hline $\begin{array}{l}\text { Penilaian } \\
\text { penampila } \\
\mathrm{n}\end{array}$ & $\begin{array}{l}\text { Belum } \\
\text { baik }\end{array}$ & $\begin{array}{l}\text { Tidak } \\
\text { memperha } \\
\text { tikan } \\
\text { Berpenam } \\
\text { sesuai } \\
\text { kondisi }\end{array}$ & $\begin{array}{l}\text { Tidak terlalu } \\
\text { memperhatikan }\end{array}$ \\
\hline \multicolumn{4}{|c|}{ Self Ethic-Moral } \\
\hline & Aturan & Mengikut & $\begin{array}{l}\text { Boleh } \\
\text { melanggar dan } \\
\text { tidak baik }\end{array}$ \\
\hline
\end{tabular}

yang lebih pada mereka dibandingkan pada remaja pada umumnya. Dalam berperilaku dengan teman dan lingkungan sosial lain di luar keluarga, ketiga narasumber tidak menunjukkan kesulitan dalam beradaptasi dan melakukan hubungan dengan orang lain. Namun ketiganya memiliki kedekatan dengan lingkungan yang beragam.

Setiap orang memiliki penilaian terhadap dirinya masing-masing berdasarkan perilaku yang dilakukannya. Dalam memandang perilaku masingmasing narasumber, ketiganya tidak memberikan penilaian yang positif bagi perilaku yang dilakukannya. Sebagian besar penilaian tersebut berkaitan dengan nilai dan harapan orangtua narasumber. Persepsi dan penilaian remaja mempengaruhi rasa berharga pada diri sendiri.

\section{Dimensi Eksternal}

\begin{tabular}{|c|c|c|c|}
\hline & $\begin{array}{l}\text { berintera } \\
\text { dengan }\end{array}$ & $\begin{array}{l}\text { dan norma } \\
\text { keluarga } \\
\end{array}$ & $\begin{array}{l}\text { selama dalam } \\
\text { batas kewajaran }\end{array}$ \\
\hline \multicolumn{4}{|c|}{ Personal Self } \\
\hline $\begin{array}{l}\text { Pengetahu } \\
\text { kekuranga }\end{array}$ & $\begin{array}{c}\text { Tidak } \\
\text { mengeta }\end{array}$ & $\begin{array}{l}\text { Mengenal } \\
\text { kelebihan } \\
\text { kekuranga }\end{array}$ & $\begin{array}{l}\text { Mengenali } \\
\text { kekurangan }\end{array}$ \\
\hline $\begin{array}{l}\text { Mengatasi } \\
\text { mengemb }\end{array}$ & $\begin{array}{l}\text { Tidak } \\
\text { dan } \\
\text { mengem }\end{array}$ & \begin{tabular}{l|} 
Dapat \\
mengemb \\
kelebihan
\end{tabular} & $\begin{array}{l}\text { Dapat } \\
\text { kekurangan }\end{array}$ \\
\hline \multicolumn{4}{|c|}{ Family Self } \\
\hline Peran di & $\begin{array}{c}\text { Merasa } \\
\text { memiliki }\end{array}$ & Memiliki & $\begin{array}{l}\text { Mengetahui } \\
\text { peran namun } \\
\text { tidak } \\
\text { melaksanakan }\end{array}$ \\
\hline \multicolumn{4}{|l|}{ Social Self } \\
\hline $\begin{array}{l}\text { Berpartisip } \\
\text { asi dengan } \\
\text { lingkungan }\end{array}$ & OSIS & $\begin{array}{l}\text { Guru Ngaji } \\
\text { dan remaja } \\
\text { pengurus }\end{array}$ & Pecinta alam \\
\hline
\end{tabular}

Tabel 7 Dimensi eksternal antar subjek

Berdasarkan pada penilaian narasumber terhadap diri sendiri, narasumber memberikan beberapa penilaian fisik tentang penampilan dirinya. Farhan dan Ahmad tidak terlalu memperhatikan penampilannya , keduanya cenderung berpenampilan apa adanya dan menyesuaikan dengan 
kondisi. Berbeda dengan Muthi, Muthi menilai penampilannya belum baik dan tidak merasa puas. Menurut Muthi, penampilannya saat ini belum sesuai dengan ajaran Islam. Muthi masih melanggar dan tidak patuh pada orangtua yang mengingatkan dan mengarahkannya untuk menjaga auratnya. Namun ketika disekolah, Muthi merasa memiliki penampilan yang alim. Hal ini sesuai dengan pendapat teman sekolahnya tentang dirinya. Memang dibandingkan dengan teman-teman di sekolahnya, Muthi memiliki penampilan yang lebih religius.

Setiap orang memiliki standart dan prinsip. Tidak semuanya memiliki penekanan pada prinsip yang sama, walaupun sama-sama berasal dari keluarga da'i. Muthi memiliki beberapa prinsip yang ia pegang. Sebagai remaja yang telah diajarkan nilai-nilai agama, Muthi memperhatikan aturan agama yang berkaitan dengan interaksi dengan lawan jenis dan tata cara berpakaian. Prinsip ini sangat diperhatikan Muthi saat ia bergaul dan berinteraksi dengan teman laki-laki. Berbeda dengan Farhan, Farhan tidak terlalu menekankan prinsip tertentu. Sehingga tidak ada perilaku khusus yang dilarang. Farhan cenderung memperbolehkan banyak hal selama tidak berlebihan dan sangat menyimpang dari nilai-nilai agama dan masyarakat. Pada Ahmad, awalnya ia memiliki prinsip yang sedikit mirip. Menurut Ahmad mencoba hal yang melanggar norma dan aturan agama tidak masalah karena hanya mencoba karena penasaran. Setelah memutuskan untuk berubah, Ahmad cenderung berusaha untuk memenuhi dan menjalankan nilai dan norma yang berlaku dalam agama dan masyarakat.

Berdasarkan pada pengenalan terhadap diri, Muthi, Ahmad dan
Farhan belum mengenali kelebihan dan kekurangan yang dimiliki. Ketiganya lebih mudah mengungkapkan kekurangan yang dimiliki dibandingkan dengan kelebihan yang dimiliki. Sebagian besar belum mengetahui seluruh kelebihan yang dimiliki secara keseluruhan. Ahmad dan Farhan saat menyadari kelemahan dan penghambatnya, mereka berusaha untuk mengatasinya. Namun pada Muthi, ia belum benar-benar mengenali kekurangannya. Muthi baru menyadari kesalahan-kesalahan yang ia miliki.

Pada diri keluarga, Muthi, Ahmad dan Farhan memiliki peran dan hubungan yang beragam dengan keluarganya. Hubungan Muthi dengan orangtua serta saudaranya menunjukkan hubungan yang tidak terlalu dekat. Berbeda dengan Ahmad, ia memiliki hubungan yang akrab dengan saudara dan orangtuanya. Walaupu tidak memiliki pengaruh secara signifikan dalam keluarga, Ahmad merasa memiliki peran dalam keluarganya. Tidak demikian denfan Farhan, dalam keluarga, Farhan tidak memiliki hubungan yang sangat akrab dengan kakak-kakaknya. Sebagai anak terakhir, tidak jarang Farhan merasa keberatan dengan kakak-kakak yang memaksakan pemikirannya kepadanya. Berdasarkan diri sosial narasumber, Muthi, Ahmad dan Farhan berpartisipasi di lingkungan sosial. Ketiganya memiliki kegiatan-kegiatan yang dilakukan di lingkungan pertemanan.

\section{Kesimpulan}

Berdasarkan sanctification orangtua pada tipe manifestation of God, Orangtua menyadari bahwa menjalankan peran sebagai orangtua adalah tugas yang mulia, sebagai mana Islam memandang kedudukan orangtua. Semua narasumber menyadari bahwa ia menjadi teladan dan contoh bagi anak-anaknya. 
Pemaknaan ini memberikan dorongan kepada orangtua untuk berusaha menjalankan perannya sebagai orangtua dengan baik dan menjadi pribadi yang lebih baik lagi. Orangtua dalam menjalankan perannya mengajarkan berbagai nilai-nilai Islam dan menjalankan syariat Islam. Orangtua berusaha untuk mengajarkan tentang kehadiran Allah dalam setiap aspek kehidupan. Orangtua selalu berusaha untuk menjaga anak-anaknya agar sesuai dengan ajaran agama Islam dan tidak melanggar ajaran Islam. Orangtua melakukannya melalui, nasihat, do'a, dan dialog.

Pemaknaan orang tua dengan tipe sacred quality membuat orang tua memaknai perannya dengan karakter kemuliaan dan kenikmatan. Karakter tersebut muncul karena para narasumber merasakan bahwa kedudukan peran orangtua dalam kehidupan anak dan kesempatan menjadiorangtua tidak dimiliki oleh setiap orang. Orangtua juga memahami hubungan mereka dengan anak sebagai hubungan yang mulia. Sedangkan anak dan keberadaannya ditengah keluarga, dimaknai sebagai sebuah keberkahan dan keajaiban. Orangtua menepis keresahan yang biasanya dialami oleh orangtua pada umumnya tentang sulitnya menanggung biaya hidup seorang anak.

Konsep diri merupakan penilaian remaja terhadap dirinya, pada dimensi internal, remaja memiliki penilaian terhadap diri yang cenderung negatif karena tidak sesuai atau bertentangan dengan harapan orangtua dan ajaran Islam. Ketiga remajapun merasakan dirinya sebagai anak pendakwah berbeda dengan remaja pada umumnya. Namun identitasnya sebagai anak dari keluarga dai tidak diterima sepenuhnya. Namun hal ini tidak membuat mereka menarik diri dari lingkungan sosialnya.
Berdasarkan dimensi eksternal, ketiga remaja sebagian telah mengetahui kekurangannya dan sebagian besar belum mengenal dengan baik kelebihan yang dimiliki. Sehingga belum dapat mengembangkan potensi yang dimiliki. Walaupun demikian, ketiganya berpartisipasi dengan lingkungan. Sesuai dengan nilai-nilai yang diajarkan keduaorangtuanya Ketiganya bergabung dalam organisasi dan komunitas. Mereka dapat beradaptasi dengan lingkungannya dan tetap menyesuaikan dengan norma agama atau menyesuaikan dengan teman. Ketiga remaja dalam pergaulannya selalu berusaha untuk memegang nilai-nilai yang menjadi prinsip. Minimal nilai tersebut tidak melanggar norma yang berlaku di masyarakat.

\section{Saran}

Berdasarkan hasil penelitian yang dilakukan, terdapat beberapa saran yang dapat peneliti berikan untuk pengembangan penelitian yang berkaitan dengan sanctification of parenting dan remaja keluarga da'i, yaitu:

1. Masih diperklukan lebih banyak penelitian yang berkaitan dengan sanctification of parenting pada orangtua yang beragama Islam baik dalam bentuk penelitian kuantitatif dan kualitatif.dengan kelompok dan kasus yang lebih bervariasi.

2. Peneliti selanjutnya dapat melakukan penelitian kepada remaja keluarga da'i yang lebih dengan menggali lebih dalam mengenai konsep diri dan faktor-faktor yang mempengaruhinya.

\section{Reference}

Akhiruddin. (2017). Urgensi Keteladanan dalam Keluarga: Sebuah Refleksi Dakwah Rosulillah pada Keluarganya. Kordinat. (16). 349-366 
Calhoun F, Acocella. 1990. Psikologi tentang Penyesuaian dan Hubungan Kemanusiaan. Edisi Ketiga. Semarang :IKIP Semarang Press

Dehart, G.B., Sroufe, L.A \& Cooper, R.G. (2004). Child development: Its Nature and Course (5th ed). New York: McGraw Hill Companies

Fitts, W.H., (1971). The Self Concept and Self Actualization. California:Western Psychological Services.

Hasan, Aliah B.Purwakania.(2008). Psikologi Perkembangan Islami: Menyikapi Rentang Kehidupan Manusia Prakelahiran hingga pascasarjana, Jakarta: PT. Raja Grafindo Persada

Mahoney, A., Pargament, K. I., Tarakeshwar, N., \& Swank, A. B. (2001) Religion in the home in the 1980s and 1990s: A meta-analytical review and conceptual analysis of links between religion, marriage, and parenting. Journal of Family Psychology, 15, 559-596

Mahoney,Annette, Pargament,I.Kenneth, Murray-Swank,Aaron, \& MurraySwank, Nichole. (2003). Religion and the Sanctification of Family Relationship. Review of Religious Research. (44). 220-236.

Marcia, J.E.,et.al. (1993).Egi Identity: A Handbook for Psichological Research. New York: SpringerVerlag

Marsh, W. Herbert, Craven, R.G. \& Debus, R. (1998). Structure, Stability, and Development of Young Children's Self-Concept: A MulticohortMultioccasion Study. Child Development, 69.1030-1053.Middlebrook,P.N. (1980). Social Psychology anf Modern Life. New York : Alfred A
Niaraki, Rezai Fahimeh \& Rahimi, Hassan. (2013) The Impact of Authoritative, Permissive, and, Authoritarian Behavior of Parents on Self-Concept, Psychological Health and Life Quality. European Online Journal of natural and social science. Vol. 2, No. 1.

Pargament. K.I., \& A. Mahoney, (2005). Theory:" Sacred Matters: Sanctification as a Vital Topic for the Psychology of Religion”. International Journal for The Psychology of Religion. 15(3). 179-198.

Rahman, Ab. Othman, dkk. 2017. The Relationship Between Parenting Style and Self Concept.Journal of Education and Social Science. Vol.7. No. 1.H1m.190-194

Santrock, J.W.2010. Remaja (edisi ketigabelas). Jakarta : Erlangga

Utting, David. (2007). Parenting and the Different Ways it Can Affect Children's Lives:

Research Evidence. Joseph Rowntree Foundation

'Ulwan, Abdullah Nashih. 2016. Tarbiyatul Aulad fil Islam: Pendidikan Anak dalam Islam Sukoharjo: Insan Kamil.

Suwaid, Muhammad Nur Abdul Hafizh (2010).Propethic Parenting: Cara Nabi Mendidik Anak. Yogyakarta: Pro-U Media

Tajfel, H., \& Turner, J. (1979). An integrative theory of intergroupconflict. In W. Austin \& S. Worchel (Eds.), The social psychology of intergroup relations (pp. 33-47). Pacific Grove, CA: Brooks/Cole

Volling, B.L, Mahoney, A \& Rauer, A.J (2009).Sanctification of Parenting, Moral Socialization and Young Children's Concsience Development. Journal Psychology of Religion and Spirituality. Vol.1 (1). Hlm. 53-68. 